\title{
Produção da concórdia a poética do poder na América portuguesa (sécs. XVI-XVIII)*
}

\author{
Producing concord \\ the poetics of power in Portuguese America \\ $\left(16^{\text {th }}-18^{\text {th }}\right.$ centuries)
}

\begin{abstract}
G UILHERME AMARAL LUZ
Doutor em História pela UNICAMP

Docente do INHIS/UFU

Av. J oão Naves de Ávila, 2160. Campus Santa Mônica. Bloco IH. Sala IH-40.

Bairro Santa Mônica. CEP 38400-902 - Uberlândia, MG - Brasil

guilherme_a_luz@yahoo.com.br
\end{abstract}

RESUMO O objetivo deste artigo é traçar, em linhas gerais, os princípios retóricos, políticos e teológicos que acreditamos nortear a propaganda imperial portuguesa em seu contexto ultramarino na América. Nessa direção, propomos tomar a "produção da concórdia" como um eixo axiológico fundamental das representações políticas na América portuguesa. A relevância deste estudo está na consideração de instâncias (re)produtoras de valores éticos e políticos capazes de mediar os diversos pactos que se estabelecem entre súditos ultramarinos e coroa portuguesa na condução dos assuntos coloniais.

Palavras-chave propaganda política, concórdia, América portuguesa (sécs. XVI-XVIII).

\footnotetext{
* Artigo recebido em: 07/02/2006. Aprovado em 20/10/2006.

(Este texto é resultado parcial do projeto de pesquisa: O Heroísmo Militar do Governo Geral na América Portuguesa (1563 - 1676): uma leitura histórico-retórica de De Gestis Mendi de Saa e Vida o Panegvirico funebre al Senor Alfonso Furtado Castro do Rio Mendomcà, para o qual conto com o importante apoio da FAPEMIG. Pela leitura atenta das primeiras versões deste artigo e pelas suas importantes observações, eu gostaria de agradecer o amigo e colega Luís Filipe Silvério de Lima, da Unifesp-Guarulhos)
} 
ABSTRACT The aim of this article is to present the rhetorical, political and theological principles that guide the Portuguese imperial propaganda in its overseas' contexts, especially in America. Its proposal is to take that what it calls 'production of concord' as the axiological fundament of political representation in Portuguese America. The pertinence of the proposal is to approach the means through which ethical and political values are propagated in the colony, mediating 'pacts' between overseas' vassals and the Portuguese crown.

Key words political propaganda, concord, Portuguese America (16th-18th Centuries).

Outro dia, procurou saber de pessoa inteligente, que pessoas eram aquelas as que concorriam no palácio, assim por suas ocupações como por dependências, de cuja diligência alcançou saber que ocorria entre algumas delas, mas principais, não se falarem, com que os mandou chamar e fez amigos, dizendo-lhes não ser justo que Havendo de andar em sua presença, não era justo que houvesse entre eles ódios, nem rixas, o que todos com muito Agrado, todos fizeram, rendendoIhe graças, Exercitando, nesta sua primeira ação o que Cristo, senhor nosso, tanto encomendou a seus discípulos. O que, no meu sentir, é uma espécie de divindade, pois onde ela assiste não falta Deus, efeito que nos mostra que não faltaria no coração de Nosso Herói. ${ }^{1}$

Nas últimas décadas, tanto em Portugal quanto no Brasil, vem surgindo uma gama de trabalhos que têm revisitado a questão da administração do império ultramarino português entre os séculos XVI e XVIII. Mais do que fazer um balanço dessa produção, o presente artigo tem como objetivo refletir a respeito dos desafios que ela vem instituindo para a escrita da história daquele momento, repensando noções tais como a de pacto colonial, subordinação da colônia aos interesses metropolitanos, centralização política e outras tantas, caras à historiografia sobre o período. Pretendemos atentar para a nova leitura que se propõe a respeito daquilo que vem sendo chamado de economia política de privilégios e do lugar das colônias na monarquia corporativa portuguesa, propondo, em seguida, um redirecionamento das atenções no caminho do estudo das práticas de representação e propaganda políticas, que, em suas modalizações retórico-poéticas e teológico-políticas, colaboram para a consolidação do domínio ultramarino lusitano.

1 SIERRA, J. L. As excelências do Governador: o panegírico fúnebre a D. Afonso Furtado (Bahia, 1676). São Paulo: Companhia das Letras, 2002, p.98-99. 


\section{Debates em torno do "pacto colonial"}

Um dos aspectos mais debatidos na historiografia sobre a América portuguesa colonial é relativo à sua administração, particularmente no que se refere ao seu lugar político em relação à metrópole e às demais possessões ultramarinas de Portugal nos séculos XVI, XVII e XVIII. Desde pelo menos os trabalhos de Caio Prado Júnior, tal questão aparece ligada ao fenômeno mais geral da formação de uma economia capitalista de caráter mercantil, colocando-se em primeiro plano o pacto econômico entre metrópole e colônia de exploração, o que implica dependência da segunda em relação à primeira, por meio de mecanismos centralizados de controle da administração e de proteção comercial. Partindo dos insights de Prado Júnior, Fernando Novais idealizou, na década de 1970, a teoria do "Antigo Sistema Colonial": uma engenhosa máquina explicativa do funcionamento das relações entre metrópole e colônia, articulado às transformações históricas do mundo capitalista entre os séculos XVI, XVII e XVIII, que culminariam com a crise do próprio sistema, devido às suas contradições necessárias, na época da Revolução Industrial. ${ }^{2}$

A teoria do Sistema Colonial, proposta por Novais, e inaugurada, de certa forma, por Prado Júnior, teve e ainda tem ampla influência na historiografia brasileira. No entanto, já na década de 1970, Ciro Flamarion Cardoso, por exemplo, questionava o que via como uma espécie de hipertrofia do papel das políticas mercantilistas de extração de excedente na análise das estruturas sociais e políticas da colônia, propondo, no seu lugar, um olhar particularizado e comparativo sobre várias situações de "colônias de exploração" capaz de dar conta das relações locais como fundantes de suas estruturas políticas, econômicas e sociais. ${ }^{3}$ Pode-se dizer que, enquanto Novais defendia uma interpretação da colonização com base na sua relação com os interesses metropolitanos, Cardoso defendia uma leitura da colonização com base nas particularidades da exploração metropolitana nas diversas áreas coloniais. Grosso modo, em termos administrativos, a colônia poderia ser vista ou como reflexo de interesses mercantis da burguesia comercial portuguesa, protegida pelas políticas mercantilistas do Estado, ou como fruto das configurações sociais que se davam no âmbito local, ainda que as duas possibilidades fossem passíveis de combinação.

No caso da adoção da perspectiva de que a administração colonial seria um reflexo de interesses mercantis da metrópole, a constatação da existência, na América portuguesa, de mecanismos descentralizados de

2 Nos referimos aos "clássicos": PRADO JÚNIOR, C. Formação do Brasil Contemporâneo. São Paulo: Brasiliense 1976 e NOVAIS, F. Portugal e Brasil na crise do Antigo Sistema Colonial (1777-1808). São Paulo: Hucitec, 1979.

3 Ver: CARDOSO, C. F. As concepções acerca do 'Antigo Sistema Colonial': a preocupação obsessiva com a 'extração de excedente'. In: LAPA, J. R. A. (org.) Modo de produção e realidade brasileira. Petrópolis: Vozes, 1980, p.109-132. 
exercício de poder pelas elites locais poderia ser tomada de duas maneiras, muitas vezes, complementares: (1) como sintoma da falta de uma racionalidade administrativa centralizada e eficaz ou (2) como uma conquista de autonomia relativa das elites locais a despeito da vontade da coroa portuguesa. Em certa medida, essa leitura recupera lugares comuns de historiadores oitocentistas, como, por exemplo, João Francisco Lisboa, que via a administração colonial como caótica, arbitrária e pouco ordenada, abrindo espaços para o favorecimento pessoal dos "homens bons" e para a corrupção. ${ }^{4}$ Nesse caminho, não raro se encontra uma dicotomia entre o poder local - exercido principalmente no âmbito das câmaras municipais - e o metropolitano - expresso em instituições como o Governo-geral e o Conselho Ultramarino, por exemplo. No caso de Novais, essa dicotomia é traduzivel como a própria contradição do Sistema Colonial, pois não haveria como explorar a colônia sem desenvolvê-la, ou seja, sem se gerar um grupo socialmente abastado na colônia capaz de perceber, paulatinamente, que seus interesses nem sempre convergem com os da metrópole, o que se intensificaria nas últimas décadas do século XVIII no contexto da Revolução Industrial. ${ }^{5}$

Em uma direção distinta, Russell-Wood, discípulo de Charles Boxer, defende, a partir da teoria de Jack Greene sobre centro e periferias no mundo colonial, que: "as falhas no sistema de administração metropolitana, as políticas mal concebidas e inconsistentes da Coroa em relação à colônia, a falta de flexibilidade na implementação de ordens, e o malogro em reconhecer o caráter singular do Brasil, contribuíram para tornar frágil a autoridade dos conselhos metropolitanos". E segue afirmando que: "a história da colônia apresenta-se como uma trajetória em direção a uma crescente erosão dos princípios sobre os quais a metrópole havia construído um pacto colonial, assim como à progressiva afirmação da participação por parte da periferia". Para Russell-Wood, portanto, a administração do Brasil se dar segundo os interesses metropolitanos seria o que se esperar da lógica do sistema colonial. ${ }^{6}$ Nisso, ele não se difere daqueles que vêem nas falhas do sistema caminhos através do quais os colonos conquistaram relativa autonomia a despeito da vontade metropolitana. A diferença de sua abordagem está na sua observação a respeito do que seria uma espécie de inversão lógica na prática política colonial do Império português, tornando o sistema colonial, no limite, uma abstração (ou uma espécie de "ideal tipo") que se desfaz ao longo dos três séculos de colonização.

4 LISBOA, J. F. Apontamentos e observações para servir à história do Maranhão. In: Crônica do Brasil Colonial. Petrópolis: Vozes, 1976, p.385-429.

5 NOVAIS, F. Portugal e Brasil na crise do Antigo Sistema Colonial (1777-1808), p.106-116.

6 Ver: RUSSELL-WOOD, A. J. R. Centros e Periferias no Mundo Luso-Brasileiro, 1500-1808. Revista Brasileira de História, São Paulo, vol.18, n.36, 1998. 
O pressuposto de Russell-Wood permanece muito semelhante ao de Novais, Prado Júnior e outros que defenderam a teoria do Sistema Colonial. Isto é: a centralização administrativa, para todos eles, figura como ideal político perseguido pelas instâncias metropolitanas. Na base desse pressuposto encontra-se um outro: o de que a monarquia ("absolutista"), tipicamente falando, teria como princípio a centralização das decisões nos círculos mais próximos do rei, reservando espaços bastante limitados de exercício político por parte dos cidadãos (aristocracia ou nobreza civil). Se não se revêem, em alguma medida, esses pressupostos, a tarefa de se compreender os espaços de exercício político dos coloniais a não ser como inversão ou subversão da lógica do sistema torna-se difícil; fazendo de instituições como, por exemplo, as câmaras municipais indesejáveis, porém inevitáveis, instrumentos administrativos centrífugos e contraditórios em relação à ordem política "ideal". Por outro lado, Russell-Wood torna bastante evidente o que poderíamos chamar de uma anomalia presente no paradigma do Antigo Sistema Colonial, que, no atual estágio de investigação sobre a administração da América portuguesa, vem permitindo a construção de uma nova visão global a respeito da colonização.

António Manuel Hespanha foi um dos primeiros estudiosos a rever a teoria do "poder absoluto" e da "centralização política" no caso da monarquia portuguesa do "Antigo Regime". ${ }^{7}$ Fazendo uma síntese de sua proposta, Hespanha, respaldando-se em estudos posteriores ao seu, realizados em Portugal, caracteriza o que denomina "monarquia corporativa", adequada, ao seu ver, à monarquia portuguesa até pelo menos meados do século XVIII. Em primeiro lugar, ressalta que "o poder real partilhava o espaço político com poderes de maior ou menor hierarquia". Em segundo lugar, afirma que "o direito legislativo da Coroa era limitado e enquadrado pela doutrina jurídica (ius commune) e pelos usos e práticas jurídicos locais". Em terceiro lugar, reconhece uma subordinação dos deveres políticos aos deveres morais, aos laços afetivos de amizade e às redes clientelares. Por último, percebe uma proteção dos direitos e atribuições dos oficiais da Coroa, o que lhes garantia confrontar com a própria autoridade real sem, contudo, suplantar o seu poder. É desse contexto político que, segundo Hespanha, aflorará o que denomina "estrutura administrativa centrífuga" das possessões no ultramar, formada por uma heterogeneidade de laços políticos entre os vassalos e o rei e pela possibilidade de adaptação (e até mesmo anulação) das determinações reais no âmbito das instituições políticas locais e de sua autonomia decisória. ${ }^{8}$

7 Nos referimos a: HESPANHA, A. M. As Vésperas do Leviathan: instituições e poder político - Portugal: Século XVII. Coimbra: Almedina, 1994.

8 Ver: HESPANHA, A. M. A constituição do Império português. Revisão de alguns enviesamentos correntes. In: FRAGOSO, J. et alli (orgs.) 0 antigo regime nos trópicos. Rio de Janeiro: Civilização, 2001, p.163-188. 
A monarquia corporativa caracterizada por Hespanha não é uma invenção portuguesa, nem tampouco uma estrutura política que surge ex machina face às transformações da chamada "modernidade". Ela resulta de formas históricas complexas de se entender as fontes do poder político e a legitimidade de seu exercício, que se desenvolvem durante séculos em um processo contínuo de "releituras" de fontes autorizadas oriundas da tradição letrada do ocidente e de práticas políticas (que também são sociais e culturais) inscritas na "longa duração". Nesse sentido, o estudo clássico de Ernst Kantorowicz sobre a teologia política medieval ajuda a entender historicamente o tipo de pacto que se estabelece entre súditos e rei nesta forma de configuração monárquica. Fundamental, aqui, é a reflexão, apresentada por Kantorowicz, sobre o caráter corporativo da coroa. Para esse autor, a coroa é "superior a todos os membros individuais, inclusive o rei, ainda que não separada dos mesmos". A coroa é um corpo composto, segundo uma hierarquia particular, pelo rei e pelos magnatas, co-responsáveis pela condução do corpus mysticum. ${ }^{9} \mathrm{Na}$ teologia política neo-tomista, própria do universo político ibérico dos séculos XVI, XVII e XVIII, tal noção de coroa se articula à tópica da "obediência ao poder público" como algo inscrito na lei natural. Para Francisco de Vitoria, por exemplo, o poder da sociedade política tem sua origem na Providência, que reúne os cidadãos como parte de um só corpo, mantendo-o como uma totalidade indivisível. Assim, por um lado, o cargo real é a corporificação da união mística do povo, sob uma mesma coroa, na persona ficta do governante a quem se deve obediência; por outro, há um compromisso inalienável do rei com os cidadãos na distribuição da responsabilidade em relação ao bem comum. Tanto na concepção humanista quanto na escolástica, esse compromisso se volta à manutenção da paz e à promoção da concórdia, tendo em vista assegurar a preservação da polis, entendida aristotélica e antimaquiavelicamente como locus de exercício da ética e das virtudes humanas (no caso, fortemente marcadas por uma releitura cristã). ${ }^{10}$

Voltando à estrutura administrativa "centrífuga" da América portuguesa, depois dessa breve digressão a respeito da teologia política da monarquia

9 KANTOROWICZ, E. H. Os dois corpos do Rei: um estudo sobre teologia política medieval. São Paulo: Companhia das Letras, 1998, p.226-232.

10 Sobre as teorias quinhentistas e seiscentistas a respeito das origens e finalidades da sociedade política, utilizamos: LLOYD, H. A. Constitucionalism. In: BURNS, J. H. (ed.) The Cambridge History of Political Thought (1450 - 1700). Cambridge: Cambridge University Press, 1991, p.258-264. Para uma visão geral a esse respeito no neo-tomismo, sugerimos: SKINNER, Q. O ressurgimento do tomismo. In: As fundações do pensamento político modemo. São Paulo: Companhia das Letras, 1996, p.414-449. Sobre o papel da política como lugar por excelência do exercício da ética e das virtudes humanas para Aristóteles, ver o panorama de suas obras sobre ética e sobre política apresentado em: TAYLOR, C.C.W. Politics. In: BARNES, J. The Cambridge Companion to Aristotle. Cambridge: Cambridge University Press, 1996, p.233-258 \& HUTCHINSON, D. S. Ethics. In: BARNES, J. The Cambridge Companion to Aristotle, p.195-232. A recepção das teses éticas e políticas de Aristóteles, bem como as teses dos estóicos, no ambiente político português do Antigo Regime, é tratada por: HESPANHA, A. M. As vésperas de Leviatã. Ver, também: CARDIM, P. Politics and power relations in Portugal (Sixteenth-Eighteenth Centuries). Parliament, States and Representations, vol.13, n.2, p.98, 1993. 
corporativa, pode-se dizer que, antes de ser derivada de aspectos contingenciais, da pressão de interesses locais a despeito dos metropolitanos ou das dificuldades práticas de centralização real, ela encontra ressonância no espectro político típico de uma racionalidade aristotélico-tomista, impressa na tradição. A autonomia relativa das instituições coloniais e a participação de grupos de colonos abastados em determinados lugares hierárquicos do poder ultramarino não contradizem, mas, antes, reafirmam o pacto político da modernidade ibérica. A unidade do Império português, assim, não resultaria de uma obediência cega às determinações reais, mas de uma espécie de "comunhão fraterna" entre os súditos co-responsáveis pelo bem-estar do organismo civil corporificado na Coroa. Haveria, assim, uma diversidade de lugares políticos na unidade orgânica do império ultramarino português e as suas formas de harmonização dependeriam da produção artificial da concórdia, de uma ordem fundada no "amor", de uma hierarquização reconhecidamente justa e legítima aos olhos e ouvidos dos súditos do Império.

Em resenha do livro 0 Trato dos Viventes, de Luiz Felipe Alencastro, Maria Fernanda Bicalho estabelece um diálogo com Milton Ohata, que é bastante sintomático de um novo paradigma a respeito dos laços políticos envolvendo colônia e metrópole no universo do Império português seiscentista. Alencastro defende que, no século XVII, ocorrerá uma modificação do sistema colonial que vinculará o Brasil diretamente à África Ocidental (particularmente Angola), formando um complexo econômico, social, demográfico e político comum às áreas escravistas da América portuguesa e às áreas africanas de trato negreiro. Segundo Bicalho, Ohata entendeu que a "autonomia do comércio bilateral e do colonato brasílico" tornava, na análise de Alencastro, a colônia autônoma em relação à metrópole naquilo que Ihe era economicamente imprescindível, contradizendo a lógica do pacto colonial. Daí sua pergunta: o que então poderia ter garantido que o Brasil continuasse sendo politicamente subordinado a Portugal ainda por tanto tempo? Para responder tal pergunta, Bicalho argumentará que o primeiro passo é rever a noção de pac to colonial, que, para ela, tem de ser pensada mais em termos de suas configurações políticas do que em termos de suas dimensões econômicas, como aparece em Novais, por exemplo.

Dois autores aparecem, na argumentação de Bicalho, para exemplificar o que seriam as configurações políticas do pacto colonial. O primeiro é Evaldo Cabral de Mello, que, em Rubro Veio, trabalha um imaginário político típico do Antigo Regime português relativo ao contrato ou pacto entre os súditos e o rei presente na auto-representação dos pernambucanos, que reivindicavam "honras, mercês e cargos" em troca de terem se empenhado na restauração da terra para a coroa à custa de perdas pessoais. $\mathrm{O}$ segundo é Charles Boxer que, em seu trabalho sobre Salvador Correia de Sá, demonstrou a trajetória exemplar de um funcionário da administração 
ultramarina que representava, ao mesmo tempo, os interesses de grupos "brasílicos" e "agentes da construção da soberania lusitana no Atlântico Sul". Bicalho concluirá que, na perspectiva do Império e no interior do mesmo, "tanto o 'homem ultramarino', quanto o 'homem colonial' são ambos produto de redes e interesses comerciais e políticos, que lhe teceram não apenas a geografia, mas também a soberania". ${ }^{11}$ Isso quer dizer, em outros termos, que, buscando de forma complementar ascenderem social e politicamente no interior das regras do jogo político do Antigo Regime e enriquecerem através da atuação econômica em um determinado enclave colonial, os súditos do Império Português que se espalhavam pelas possessões ultramarinas construíam as condições do domínio imperial no interior do qual se viam integrados, conforme uma hierarquia particular.

Um dos caminhos da "nova historiografia política" sobre o Império ultramarino português tem sido, portanto, identificar os elementos da sua cultura política que possibilitam a produção da concórdia, ainda que a isso se atribua muitos outros nomes. Bicalho, a partir da leitura de autores como Ângela Barreto Xavier, Antônio Manuel Hespanha, Evaldo Cabral de Mello, João Fragoso e, principalmente Fernanda Olival, nomeia "a base fundadora de uma cultura política do Antigo Regime - tanto na Europa, quanto nos trópicos" com a expressão "economia da mercê". Isto é, uma "cadeia de obrigações recíprocas" entre súditos (ultramarinos, coloniais ou reinóis) e monarca em que os primeiros devem ser recompensados pelo segundo na forma de honras, mercês e privilégios em reconhecimento de seus serviços prestados à coroa. Desse modo, compreender a administração colonial implica considerar o papel da distribuição de cargos e mercês àqueles que são reconhecidos como servos leais à coroa e que dela estão a serviço no interior de seu projeto imperial. A "liberalidade régia", tópica que fundamenta o próprio mecanismo de funcionamento da economia da mercê - também chamada, por vezes, de economia política de privilégios - ${ }^{12}$, liga-se à "bondade do monarca", como "meio para obtenção do amor e da submissão dos súditos". ${ }^{13}$ Em outros termos, ela busca a concórdia

11 Ver: BICALHO, M. F. B. Monumenta Brasiliae: o Império Português no Atlântico-Sul. Tempo, Rio de Janeiro, vol.06, $n^{\circ}$.11, p.267-273, 2001. O texto é uma resenha do livro: ALENCASTRO, L. F. O trato dos viventes: formação do Brasil no Atlântico Sul. São Paulo: Companhia das Letras, 2000. A razão para a utilização da resenha e não do livro em si, neste artigo, está em querermos focalizar nem tanto as idéias de Alencastro em si, mas algumas leituras provocadas pelo seu livro, em especial por aqueles que defendem uma revisão da teoria do pacto colonial, como é o caso de Fernanda Bicalho.

12 Maria de Fátima Gouvêa considera que a economia política de privilégios define uma "dinâmica que pode reforçar os laços de sujeição e o sentimento de pertença dos vassalos - sejam eles reinóis ou ultramarinos - à estrutura política mais ampla do Império, viabilizando melhor o seu governo". Cf.: GOUVÊA, M. F. S. Poder político e administração na formação do complexo atlântico português (1645-1808). In: FRAGOSO, J. et alli. (orgs.) 0 antigo regime nos trópicos. Rio de Janeiro: Civilização, 2001, p.287.

13 Cf.: BICALHO, M. F. B. Pacto colonial, autoridades negociadas e o império ultramarino português. In: SOIHET, R.; BICALHO, M. F. B. \& GOUVÊA, M. F. S. (orgs.). Culturas políticas: ensaios de história cultural, história política e ensino de história. Rio de Janeiro: Mauad, 2005, p.90-92. 
entre as partes do organismo civil ao redor de sua cabeça: lugar central de onde irradia a fonte da dádiva e da justiça distributiva.

A visão historiográfica a respeito das redes de interesses comerciais e políticos, aqui exemplificada com Bicalho e Gouveia, tem o grande mérito apontar para mecanismos administrativos e políticos fundamentais para a compreensão das relações entre súditos ultramarinos do Império Português. Contudo, para completar este quadro interpretativo, acreditamos ser relevante buscar o entendimento dos valores que norteiam o juízo sobre o mérito dos serviços políticos prestados à coroa e a formação do "sentimento de pertença" dos vassalos ao Império, que se constroem no conjunto das práticas rituais, retóricas, poéticas e imagéticas representativas da propaganda política portuguesa entre os séculos XVI e XVIII. A esse aspecto, as abordagens dessa "nova história política" da América portuguesa têm dado pouca atenção. Com efeito, escapam ao seu campo de visão, principalmente, as mediações retóricas da representação política entre dois espaços que se constroem à distância: o da cabeça do corpo místico do Império (a monarquia) e o de seus braços ultramarinos (funcionários da coroa e a "aristocracia" em domínios coloniais).

\section{Diversidade, unidade e concórdia no interior do projeto imperial}

A noção de Império Português é um conceito político que deve ser pensado para se entender as relações que se estabelecem entre os poderes metropolitanos e ultramarinos. Juridicamente falando, Portugal jamais pode ser considerada a cabeça daquele que era o único Império Católico da modernidade: O Sacro Império Romano Germânico. Mesmo quando sob o domínio habsburgo espanhol, Portugal não teve um Imperador como rei, já que Felipe II não sucedeu seu pai, Carlos V, nesse título, ainda que toda a sua imagem pública tenha sido construída sob esta figura. ${ }^{14} \mathrm{O}$ termo Império, quando utilizado para se referir aos domínios lusos na época moderna, tem, no mínimo, dois sentidos fundamentais. ${ }^{15}$ Primeiro, ele se aplica às extensões do poder soberano da coroa portuguesa sobre diversas partes do orbe. Em segundo lugar e, talvez, mais importante, remete-se a

14 Sobre a imagem imperial construída em torno de Felipe II, sugerimos: VILÀ E TOMÁS, L. lam Illustrabit Omnia: Felipe Il y el Imperio Hispânico. In: Épica e Império: imitación virgiliana y propaganda política em la épica española del siglo XVI. Barcelona: Universitat Autônoma de Barcelona, 2001), p.265-305. (Filologia, Tese de doutorado. Ver também: BOUZA ÁLVAREZ, F. J. La Majestad de Felipe II. Construción del Mito Real. In: MILLÁN, J. M. (org.) La corte de Felipe II. Madrid: Alianza Editorial, 1994, p.37-72.

15 Na verdade, há muito mais do que duas concepções possíveis para Império ao longo dos séculos XVI e XVIII. Ao longo dos séculos XIX e XX, a polissemia do termo ampliou-se ainda mais, tornando-o um conceito referente a uma diversidade enorme de fenômenos, muitas vezes contraditórios entre si. A esse respeito, sugerimos: PAGDEN, A. Spanish Imperialism and the Political Imagination. New Haven: Yale University Press, 1990; PAGDEN, A. Lords of all the world: ideologies of empire in Spain, Britain, and France, 1500-1800. New Haven: Yale University Press, 1995; MULDOON, J. Empire and Order. The concept of Empire, 800-1800. Londres, Nova lorque: Macmillan Press, 1999. Uma síntese, ainda inédita, da multiplicidade dos significados de Império no século XVII português é apresentada, com competência, em: LIMA, L. F. S. Os nomes do Império no século XVII em Portugal, 2007. (Texto mimeo) 
concepções teológico-políticas e, em certas ocasiões, inscritas em quadros proféticos, nos quais as conquistas, as navegações e a evangelização dos povos "gentílicos" assumem, recorrentemente, caráter providencial, indicativo de uma missão portuguesa no mundo: a de preparar o advento do Reino de Cristo na terra. Dentre as formulações mais engenhosas (e polêmicas) a respeito dessa missão, encontram-se, a título de ilustração, as teses vieirianas sobre o Quinto Império. ${ }^{16}$

A noção de Império pressupõe formas de relacionamento com realidades "civilizacionais" variadas, cujos critérios de diferenciação e nivelamento passam, necessariamente, pelo grau de adesão/resistência de grupos presentes nas regiões ultramarinas ao seu projeto unificador. Assim, a concepção de Império não se confunde, necessariamente, com a figura do Imperador (ou mesmo com a do Rei), mas se associa a uma espécie de missão civilizadora/cristianizadora da "nação portuguesa" por obra da providência. A formação de uma espécie de "proto-etnografia" - classificatória dos povos do orbe, presente nos diversos exemplares de "literatura de viagens", gêneros historiográficos e corografias portuguesas dos séculos $\mathrm{XVI}, \mathrm{XVII}$ e XVIII - é bastante adequada, nesse sentido, ao projeto imperial. Por um lado, ela permite um mapeamento da diversidade de "civilizações" ou "culturas" na sua relação com os portugueses. Por outro, ela indica os hábitos, as práticas, os costumes e as leis que, de certa forma (pacífica ou não), convivem ou viriam a conviver no interior da unidade possível do Império. ${ }^{17}$ Unificar a diversidade civilizacional dos povos sob o Império não significa, necessariamente, impor-lhes um modelo unilateral. Antes, trata-se de adaptar as instituições portuguesas àquilo que, em cada localidade, seja compatível com a finalidade maior do Império: a adoção universal de uma vida política inseparável do desenvolvimento das virtudes cristãs, capaz de preparar o orbe para o dia do J uízo.

Assim sendo, o Império é uma unidade composta de realidades diversas que convivem em seu interior. Nela, convivem códigos variados de leis e costumes, níveis hierárquicos de civilização, situações diversas de contato com as populações nativas, formas institucionais mais ou menos adequadas a cada domínio em que se estabelecem, além de condições materiais, ambientais e culturais que impõem políticas diferenciadas de fixação e convívio por parte dos portugueses em cada área colonial. A uni-

16 Sobre a formulação teológico-profético-política da missão portuguesa no mundo: LIMA, L. F. S. Destinos de Portugal. In: 0 Império dos sonhos: narrativas proféticas, sebastianismo e messianismo bragantino. São Paulo: Universidade de São Paulo, 2005), p.90-230. (História, tese de doutorado. Sobre o papel das profecias na construção épica da figura imperial, especialmente no caso quinhentista espanhol, é interessante: VILÀ E TOMÁS, L. Profecía y Poesía Épica: construcción de la historia y de la figura imperial en la épica quinhentista española. In: Épica e Império, p.309-363.

17 É particularmente interessante, neste sentido, a análise feita por Joan-Pau Rubiés a respeito da visão "etnográfica" de João de Barros sobre os povos de Vijayanagara e suas categorias de classificação, ver: RUBIÉS, J-P. Travel and Ethnology in the Renaissance: South Îndia through European eyes. Cambridge: Cambridge University Press, 2000, p.164-177. 
dade, por sua vez, é dá-se no princípio ético evangelizador que fundamenta a expansão imperial, na circulação de elementos materiais e culturais de várias proveniências para outras áreas de domínio e na implantação de políticas mínimas de centralização, expressas em órgãos administrativos, religiosos e jurídicos metropolitanos e coloniais. O grande desafio imperial é, portanto, em termos políticos e administrativos, a produção da concórdia entre as diversas partes da unidade do corpo místico. Dizemos concórdia e não padronização, pois, organicamente pensando, são as finalidades de cada parte - não os seus meios - que devem unificar-se. Estas finalidades devem convergir para o interesse do bem-comum ou, em outros termos, para a manutenção da soberania de uma comunidade unida pelo amor ao Rei, a Cristo e ao próximo.

Uma vez que cada domínio ultramarino particular, em si, não forma um bloco social e culturalmente uniforme - constituído sempre por níveis hierárquicos entre comunidades que nem sempre compartilham interesses comuns -, a concórdia que se deve gerar é escalonada, reverberando, na dinâmica de sua produção, os graus da hierarquia social e política, que implicam obrigações e responsabilidades diferenciadas em cada caso relativas ao bem-comum. É o escalonamento da produção da concórdia que está, por exemplo, representada no trecho de Juan Lopes Sierra que serve de epígrafe para este artigo. Nele, Sierra alude àquilo que teria sido a primeira tarefa do Governador Afonso Furtado de Mendonça relativa ao Estado do Brasil: refrear, nos ciclos mais altos da hierarquia política colonial, a discórdia entre cidadãos de grande poder e, logo, de grandes responsabilidades para com o bem-comum. Como Governador Geral, Furtado de Mendonça é o elo político entre a coroa portuguesa (cabeça do Império) e o Estado do Brasil. Sua função básica é conduzir políticas coloniais que interessem a totalidade do Império em consonância com a vontade do Rei, cumprindo os seus objetivos no plano do poder temporal. Como Governador, na presença de Furtado de Mendonça e ao seu redor, é justo que haja harmonia e concórdia entre os cidadãos de alto escalão, conforme nos apresenta o trecho citado de seu panegírico fúnebre.

Controlar as rixas através de sua autoridade e do estabelecimento da justiça é, assim, a maneira de orientar a diversidade de interesses concorrentes na colônia na direção da "comunidade de fins" do Império. Suceder na tarefa de produção da concórdia é tido, desse modo, como efeito sacramental. Teologicamente, significa estabelecer a ordem do corpo místico no exercício da autoridade de governo que emana da coroa e que irradia às diversas partes da sociedade civil, seja no reino, através do próprio rei, ou nas áreas coloniais, através dos funcionários de mais alta hierarquia, como os Governadores Gerais. Em outros termos, metonimicamente, a concórdia em torno do Governador Geral reverbera: a concórdia em torno de seu 
princípio de autoridade política (a coroa e o rei) e a união sacramental do corpo místico no amor de Cristo.

Da mesma forma que a concórdia é o elo necessário para o reconhecimento da autoridade do Governo Geral, ela também é um princípio fundamental no reconhecimento de autoridades ainda mais localizadas como, por exemplo, a autoridade do senhor junto aos seus escravos. Isso fica claro, particularmente, nos sermões de Vieira dedicados à questão da escravidão. Para o jesuíta, a autoridade do senhor não é unilateral, como exercício do que hoje chamaríamos de "direito de propriedade". Vieira entende que o cativeiro dos escravos, embora seja violento, deve ser aceito de bom grado pelos escravos como maneira de purgação dos pecados e de acesso ao corpo místico, possibilitando a sua salvação. Por isso, a única justificativa para se ter escravos é a responsabilidade do senhor quanto à evangelização dos cativos. Assim, a fonte da autoridade senhorial estaria ligada a uma série de obrigações junto aos escravos, administrando, com justiça, prudência, caridade e moderação, os castigos, os trabalhos e o cotidiano (sobretudo ligados à esfera religiosa) de suas propriedades, preservando a ordem e evitando as rebeliões ou qualquer outra forma de discórdia. Nesta concepção, a autonomização dos meios (como, por exemplo, a violência) no exercício do poder senhorial ou a sua mera aplicação coercitiva para o trabalho gerador de riquezas mundanas seria o análogo perfeito da tirania política, ou seja, ações que, no uso da autoridade, deslocam as finalidades relativas ao bem-comum para os interesses particulares, gerando discórdia e comprometendo a união do corpo místico no microcosmo da fazenda. ${ }^{18}$

\section{Propaganda política no contexto do Império}

Evidentemente, deve-se ter em vista o caráter artificial da produção da concórdia como princípio político unificador da diversidade do Império. Ela se dá com base em maciça propaganda. O que estamos chamando de propaganda política ${ }^{19}$ é um vasto repertório de práticas culturais escritas, orais, imagéticas, rituais ou performáticas que representam prescritivamente,

18 Utilizamos-nos, para essa análise a respeito da concórdia no engenho, da leitura do seguinte sermão: VIEIRA, A. Sermão décimo quarto do Rosário, pregado na Bahia, à Irmandade dos pretos de um engenho, em dia de São João Evangelista, no ano de 1633. In: Sermões, vol. IV, tomo II, Porto: Lello \& Irmão, s/d. Sobre a visão jesuítica a respeito da escravidão sugerimos, ainda: PECORA, A. Vieira, o índio e o corpo místico. In: NOVAES, A. (org.). Tempo e História. São Paulo, Companhia das Letras, 1992, p.423-461; ALENCASTRO, L. F. A evangelização numa só colônia. In: 0 trato dos viventes, p.155-187 \& VAINFAS, R. Ideologia e escravidão: os letrados e a sociedade escravista no Brasil colonial. Petrópolis: Vozes, 1986. Vale considerar que há uma ampla e polêmica discussão historiográfica a respeito das práticas senhoriais de controle e sobre as diversas formas de resistência escrava. Não é nosso objetivo, aqui, pensar, na prática, como as relações entre senhores e escravos se davam. As considerações que tecemos dizem somente respeito às justificativas jurídico-teológicas do "cativeiro justo" no interior de um sistema de aconselhamento político segundo uma lógica neo-tomista.

19 É importante, aqui, evitar a associação anacrônica do uso do termo propaganda nos séculos XVI, XVII e XVIII com os sentidos (de marketing) que ele assumiu na contemporaneidade. A palavra deve ser assumida, aqui, na sua etimologia latina, que advém de propagatio, significando, figurativamente, extensão, aumento ou prolongamento. A propaganda, assim entendida, deve significar ações, práticas e discursos cujos efeitos devem ser o de aumento 
segundo uma orientação teológico-política, a ordem hierárquica do corpo místico. ${ }^{20}$ Nesse sentido, instrumentos de catequese, sermões, cartas, festividades civis e religiosas, teatro, sátiras e muitas outras formas retórico-poéticas e/ou artísticas e performáticas podem configurar instrumentos de propaganda política, cuja meta é exatamente a produção da concórdia. Em relação ao seu público, eles podem ser voltados a comunidades mais ou menos homogêneas conforme a ocasião, o que, na grande maioria dos casos, é determinante da complexidade da combinação de signos e registros mobilizados para a produção de seus efeitos.

O elogio a personagens públicas que ocupam posição de destaque não é a única forma de propaganda política. Esta se define, muito mais precisamente, como representações da ordem hierárquica do corpo místico com profundo caráter prescritivo, através da reafirmação dos valores capazes de manter o organismo civil unido e em concórdia. Pode-se afirmar, contudo, que, entre as mais propícias ocasiões para a propaganda política, as de louvor têm especial destaque. No plano ritualístico, por exemplo, as cerimônias fúnebres têm este caráter, principalmente quando envolvem morte de pessoas ilustres. No plano textual, os versos heróicos da poesia épica, os panegíricos, os sermões e outros gêneros retóricos e poéticos capazes de serem inscritos no discurso epidítico ou demonstrativo cumprem este papel. É importante assinalar ainda que o objeto de louvor de um exemplar de propaganda política não tem necessariamente que ser uma pessoa, mas se estende a celebração de qualquer figura (uma data, um lugar, a natureza, um santo, uma instituição, a Providência, a Virgem, o Espírito Santo, a opulência...) que, no plano teológico-político, seja capaz de, em suas características, ações ou palavras excelentes, por in evidentia, exemplar, metafórica ou alegoricamente, a sacralidade, a legitimidade e a justiça da ordem vigente e de suas práticas.

Pensando em uma sociedade como a portuguesa do "Antigo Regime", seja no reino ou nas colônias, em que o estatuto de nobreza se define antes pelo mérito do que pela linhagem, ${ }^{21}$ as várias formas de elogios a varões de ações destacadas cumpririam papéis sociais importantes. Em primeiro lugar, eles prestavam a construção da fama pública de algumas personagens, aspecto decisivo para o reconhecimento de ações valorosas e virtudes morais capazes de elevar o homenageado às posições superiores

da adesão em torno de determinados valores, irradiando-os ao todo que compõe uma comunidade - no caso, política - em expansão.

20 O conceito chave para a compreensão do que estamos chamando de propaganda política é o de representação Sobre ele, ver: HANSEN, J. A. A categoria 'representação' nas festas coloniais dos séculos XVII e XVIII. In: JANCSÓ, István \& KANTOR, Íris. (orgs.) Festa: cultura e sociabilidade na América portuguesa. São Paulo: Imprensa Oficial/HUCITEC/EdUSP/FAPESP, 2001, vol.2, p.733-755.

21 Ver: NIZZA DA SILVA, M. B. O conceito de nobreza. In: Ser nobre na colônia. São Paulo: Ed. UNESP, 2005, p. 15-40. 
na hierarquia e aos cargos e honrarias de maior prestígio. ${ }^{22}$ Em segundo lugar e, provavelmente, mais decisivo, as diversas formas de encômio traduziam exemplarmente os modelos de excelências a serem imitados por aqueles que almejam alcançar posições de destaque e fama pública, conquistando honrarias e colocando-se a serviço do bem comum. Assim, os louvores favoreciam o homenageado, ajudando-o a alcançar vantagens na economia de mercês; eram úteis ao orador/poeta/historiógrafo, que ganhava a proteção do nobre; serviriam como ensinamento político e moral para aqueles que buscam alcançar maior destaque público e, além disso, colocariam em evidência os valores políticos e morais que deveriam ser cultuados por todos.

A eficácia ou não da propaganda política depende da mobilização de instrumentos imagéticos, performáticos e retóricos carregados simbolicamente, que sejam capazes de legitimar a ordem hierárquica vigente e as fontes de autoridade que ela sustenta. Em um ambiente culturalmente tão complexo como o imperial, tal carga simbólica precisaria ter propriedades capazes de mover auditórios altamente diversificados, comportando registros variados. Nesse sentido, aquilo que, por exemplo, para um fidalgo, pode ser altamente claro e persuasivo, para um índio do sertão recém introduzido na sociedade escravista, pode chegar ao extremo do indecifrável, sem qualquer efeito ou, ainda pior, com efeitos opostos àqueles que se visavam produzir. ${ }^{23} \mathrm{O}$ decoro das ocasiões e as expectativas de recepção circunscritas a determinados públicos particulares são, portanto, importantes chaves para a arquitetura da propaganda política no contexto imperial e, ainda assim, não são fianças de recepções totalmente ajustadas com a "mensagem original". Ao prescreverem valores, práticas, comportamentos, atitudes, hábitos e vontades, as representações devem estar sempre atentas às suas recepções e aos seus receptores, de modo que se constroem no diálogo entre a norma geral que procura "impor" e as circunstâncias particulares de enunciação que lhes orienta na escolha dos formatos retórico, artístico e/ou "linguageiro" mais convenientes.

A eficácia da produção da exemplaridade através do encômio só é possível, portanto, quando apresenta o ajuste das ações, características,

22 Sobre o que apresentamos aqui como fama, sugerimos a conceituação clássica de Jacob Burckhardt. Segundo o autor suíço, a busca pela fama se propaga em sociedades, como a do Renascimento italiano, em que a nobreza - identificada como nobilitas (notabilidade) - não qualifica um homem tanto pela sua origem familiar, mas pelos seus méritos expressos em ações e palavras reconhecidamente valorosas, que o consagram perante os demais. Fama - pode-se dizer - é o reconhecimento público do mérito daqueles considerados nobres (nobilis). Ver: BURCKHARDT, J. A biografia na Idade Média e no Renascimento. In: A cultura do Renascimento na Itália. Brasília: Editora da UnB, 1991, p.199-207.

23 Um belo exemplo de "mal-entendidos" capazes de gerar efeitos opostos aos previstos pelo emissor dos discursos é o complexo "herético" indígena estudado por Vainfas, conhecido como "Santidade de Jaguaripe". Segundo Vainfas, foi no interior dos aldeamentos jesuíticos e a partir de uma releitura indígena dos ensinamentos dos padres sobre a Religião que a Santidade originou-se, combinando signos cristãos com práticas "gentílicas". Ver: VAINFAS, R. A heresia dos índios: catolicismo e rebeldia no Brasil Colonial. São Paulo: Companhia das Letras, 1995, p.109-117. 
aparências ou palavras do homenageado aos valores éticos reconhecidamente válidos no interior da cultura política da qual é parte. Assim, sempre há uma indissociabilidade entre o elogio encomiástico e o reforço da adesão a tais valores. Analogamente, o mesmo reforço ocorre quando a exemplaridade é produzida através de sua via negativa: o vitupério, próprio da sátira e de outras formas de escárnio, que inverte a ordem desejável por meio do desajuste das ações, características, aparências ou palavras dos infames, dos vulgos ou dos tiranos em relação aos valores válidos desta mesma cultura política. Ao colocar em evidência os vícios, ao escancararem a falta de decoro e a rudeza, os vitupérios demonstram, por inversão, as virtudes, a discrição e a sabedoria que faltam às suas personagens e que são familiares ao auditório. Os efeitos produzidos pelas inversões satíricas, tais como o repúdio, o riso e a ridicularização, dependem disto: do reconhecimento, por parte do público, dos valores que são contrariados pelos "homenageados". ${ }^{24}$

Para muitos autores, como Giulio Carlo Argan, isso que estamos chamando de propaganda política (inseparável do plano religioso) configura o cerne de uma típica vivência sócio-cultural denominada, muitas vezes, pelo termo sociedade barroca, historicamente localizada na Europa e nas periferias européias entre fins do século XVI e meados para o final do século XVIII. Nesta visão, tal sociedade seria fruto da dissolução das certezas religiosas anteriores ao cisma das Reformas, que passaria a exigir uma reafirmação constante, combativa e espetacular dos valores políticos e religiosos dos mundos católico e protestante, por meio da mobilização dos afetos e da profusão de imagens moralmente carregadas. Ainda que o termo barroco nos pareça uma generalização excessivamente dedutiva, tal concepção parece ajustar-se bem às práticas de representação e propaganda política na América portuguesa. O que essas práticas visam produzir é a imagem, ao mesmo tempo verossímil e persuasiva, do poder político e de sua legitimidade para a adesão de auditórios variados às finalidades do Estado e da Igreja. No limite, o que eles visam é a produção afetiva da concórdia (ou uma ordem fundada no amor) dos vassalos da coroa, distribuídos hierarquicamente, sem que isso se separe da sua própria razão de ser: a saúde do corpo místico do Império. ${ }^{25} \mathrm{~A}$ propaganda política se destina, pois, à

24 Um trabalho já bastante conhecido que explica a função da sátira e do escárnio como forma de reafirmação do status quo da sociedade seiscentista da América portuguesa é o estudo de João Adolfo Hansen sobre Gregório de Matos Guerra: HANSEN, J. A. A sátira e o engenho: Gregório de Matos e a Bahia do século XVII. São Paulo: Companhia das Letras, 1989. Também muito interessante, neste sentido, é o estudo de Adriana Romeiro a respeito do enterro satírico de um "mal governador" nas Minas no século XVIII. Ver: ROMEIRO, A. O enterro satírico de um governador: festa e protesto político nas Minas setecentistas. In: JANCSÓ, I. \& KANTOR, I. (orgs.) Festa: cultura e sociabilidade na América portuguesa, vol.1, p.301-309.

25 Sobre esta concepção sobre a sociedade barroca ver: ARGAN, G. C. Imagem e persuasão: ensaios sobre o Barroco, São Paulo: Companhia das Letras, 2004. A crítica relativa ao uso do termo barroco para a definição tanto da "estética" quanto das formas sociais dos séculos XVI ao XVIII é feita em: HANSEN, J. A. Colonial e Barroco. In: América: descoberta ou invenção. Rio de Janeiro: Imago, 1992, p.347-361. 
constituição de uma comunidade em torno de certos valores, legitimando os seus lugares hierárquicos, as suas instituições, a sua missão e a sua justiça aos olhos daqueles que dela são partes. A propaganda política provê o amalgama afetivo dos súditos ao Império, reduzindo as distâncias físicas na escala de suas afinidades simbólicas, gerando sentimento de pertença ao Império e reafirmando a sua hierarquia.

Mas mesmo a propaganda política não é algo que se impõe "de cima para baixo", ou seja, da realeza aos súditos. A propaganda política constrói a concórdia em constante negociação dos lugares hierárquicos e da política de privilégios, buscando distribuir, com justiça, aqueles que, "meritoriamente", anseiam por lugares hierárquicos condizentes com a sua função no interior do organismo civil. De certa maneira, a produção da concórdia não se isola daquilo que Jack Greene chamou de "autoridades negociadas". O mais central, nos argumentos de Greene, é o caráter centrífugo e consensual da construção das grandes autoridades do Império, o que se dá menos de forma violenta e coercitiva do que pela negociação com os poderes locais. ${ }^{26}$ Poderíamos pensar, por extensão, que essas negociações não são somente por posições de autoridade ou de lugares de mando no interior da burocracia, mas por posições de prestígio, fama, dignidade e reconhecimento, o que se articula perfeitamente com a economia da mercê. Assim, sem que haja subversões e descontentamentos, a propaganda política prevê ajustes constantes na auto-imagem prescritiva e pedagógica do poder, buscando sempre evitar o choque mais traumático entre as partes do corpo. ${ }^{27}$

\section{Considerações Finais: os braços do Rei e a onipresença do corpo místico}

Uma das tópicas políticas recorrentes nos exemplares épico-panegíri$\cos ^{28}$ dos domínios ultramarinos portugueses é a da articulação orgânica das ações do homenageado com a vontade do Rei. Um exemplo típico dessa articulação pode ser retirado dos versos de Basílio da Gama em 0 Uraguai, nos quais o General Gomes Freire de Andrade, dirigindo-se aos índios que resistiam à anexação das terras às colônias portuguesas, diz:

26 Ver: GREENE, J. Negociated authorities. Essays in Colonial Political and Constitucional History. Charlottesville and London: The University Press of Virginia, 1994.

27 Este processo de negociação envolvido nas formas de representação e propaganda política pode ser exemplificado na leitura realizada por Pedro Cardim a respeito das entradas solenes e festas políticas em Portugal e no Brasil entre os séculos XVI e XVII. Ver: CARDIM, P. Entradas solenes: rituais comunitários e festas políticas, Portugal e Brasil, séculos XVI e XVII. In: JANCSÓ, I. \& KANTOR, I. (orgs.) Festa: cultura e sociabilidade na América portuguesa, vol.1, p.97-124.

28 Por "exemplares épico-panegíricos" nos referimos a um conjunto amplo de gêneros poéticos e retóricos capazes de serem inscritos no discurso epidítico, como as diversas formas historiográficas, a poesia encomiástica, os poemas épicos, as dedicatórias entre outros modelos textuais. E muitos casos, esses gêneros podem gerar formas híbridas, mistas e combinadas, o que nos leva a tratá-las em bloco no que têm em comum: o objetivo de louvar ou vituperar figuras exemplares, demonstrando e reforçando valores éticos, políticos e religiosos a serem salvaguardados pelas comunidades às quais se voltam. 
"Por mim te fala o Rei: ouve-me, atende, / e verás uma vez nua a verdade." Mais à frente, continua:

O Rei é vosso Pai: quer-vos felices. / Sois livres, como eu sou; e sereis livres, / não sendo aqui, em outra qualquer parte. / Mas deveis entregar-nos estas terras. / Ao bem público cede o bem privado. / O sossego da Europa assim o pede. / Assim manda o Rei (...). ${ }^{29}$

Como se percebe, as falas do herói têm sua autoridade emanada da fonte de poder de que ele é "servo": o Rei. Em muitos outros casos, essa fonte de poder pode ser também Deus, como nos versos anchietanos dedicados a Mem de Sá, ${ }^{30}$ por exemplo. Deus ou Rei - pouco importa, pois são ambos centrais na esfera da ordem do corpo místico - é quem atua e fala através dos "braços" e "bocas" do herói: instrumento físico da realização histórica da ordenação política do mundo conforme os critérios do "justo" e do "racional". Por isso, voltando aO Uraguai, a fala do herói é capaz de por "nua a verdade". Nela, o Rei manda, ensina e reafirma o seu poder, cuja legitimidade está em preservar o "bem público" e a concórdia, no caso, "o sossego da Europa". Cabe ao herói tornar as ordens expressas em sua fonte de autoridade efetivamente cumpridas, seja através do convencimento pacífico, da administração prudente, ou do exercício das armas em guerras justas, que, no caso, será o caminho tipicamente elogiado nas construções historiográficas e, sobretudo, épicas, das quais 0 Uraguai é exemplar.

Pode-se afirmar, a partir dessas considerações, que a presença física dos heróis na resolução dos assuntos que concernem ao bem comum visa suprir a presença física do Rei nessas mesmas ocasiões. No herói, em outros termos, está sempre presente a persona ficta do Rei, que lhe guia as palavras, os gestos e as ações necessárias para o cumprimento de seu designo. A autoridade do herói é, pois, um efeito de representação; é uma presença que se faz na ausência e, assim, permite que o Rei se faça ouvido e obedecido para muito além do espaço que a sua persona personalis é capaz de alcançar. Nesse sentido, louvar as ações heróicas é uma tarefa de formação de braços do Rei em compasso com a sua autoridade e, logo, uma tarefa plena de significados políticos. O aedo épico, o panegirista, o poeta satírico ou o pregador, por exemplo, é, privilegiadamente, aquele que ensina os homens discretos como prestarem bons serviços ao Rei e ao bem comum, deleitando-os e movendo-os com seu discurso engenhoso. Em outros termos, ele é uma peça fundamental na mediação entre a cabeça e os membros do corpo místico. Por um lado, seu papel é descentralizador, por ser instrumento de uma distribuição segura do poder régio a fidalgos de além mar e da negociação de lugares políticos para esses súditos na

29 BASÍLIO DA GAMA, J. Obras Poéticas de J osé Basílio da Gama. Rio de Janeiro: Livraria Garnier, s/d, p.34.

30 ANCHIETA, J. De gestis Mendi de Saa. Rio de Janeiro: Fundação Biblioteca Nacional, 1997. Edição fac-similar de: Coimbra: Iohannem Aluarum, 1563. 
hierarquia. Por outro, seu papel é centralizador, pois busca fazer com que as ações notáveis dos que anseiam por posições de destaque subordinem-se à vontade política que irradia da cabeça do organismo civil.

Sem qualquer pretensão de esgotar o assunto, procuramos, neste artigo, traçar, em linhas gerais, os princípios retórico-político-teológicos que acreditamos nortear a propaganda imperial portuguesa no seu contexto ultramarino da América. Mostramos que seu sentido fundamental está em produzir a concórdia no interior do corpo místico, segundo uma hierarquia particular em que cabe aos notáveis papéis importantes como instrumentos da autoridade real. Não apostamos em um modelo reducionista que substitua a leitura econômica do sistema colonial por outra de caráter político e retórico. Entendemos que, caso busquemos compreender o funcionamento dos mecanismos de manutenção e ampliação dos domínios ultramarinos portugueses, seja importante levar em conta o modo de aprendizado constante por parte de seus agentes do que significa, em uma orientação teológico-política particular, ocupar uma posição socialmente destacada. Os caminhos para isso são vários, mas um deles, sem dúvida, está no estudo particularizado das formas de representação política do mundo colonial e ultramarino, mais especificamente, daquelas que compõem os vestígios retórico-poéticos que dele nos chegam. 